\title{
Exploring the status of corporate social responsibility disclosure in the UK building and construction industry
}

Article

Accepted Version

Evangelinos, K., Skouloudis, A., Jones, N., Isaac, D. and Sfakianaki, E. (2016) Exploring the status of corporate social responsibility disclosure in the UK building and construction industry. International Journal of Global Environmental Issues, 15 (4). pp. 377-399. ISSN 1466-6650 doi:

https://doi.org/10.1504/IJGENVI.2016.10001867 Available at https://centaur.reading.ac.uk/70224/

It is advisable to refer to the publisher's version if you intend to cite from the work. See Guidance on citing.

Published version at: http://dx.doi.org/10.1504/IJGENVI.2016.10001867

To link to this article DOI: http://dx.doi.org/10.1504/IJGENVI.2016.10001867

Publisher: InderScience Publishers

All outputs in CentAUR are protected by Intellectual Property Rights law, including copyright law. Copyright and IPR is retained by the creators or other copyright holders. Terms and conditions for use of this material are defined in the End User Agreement. 


\section{CentAUR}

Central Archive at the University of Reading

Reading's research outputs online 


\section{Exploring the status of corporate social responsibility disclosure in the UK building and construction industry}

\section{Konstantinos Evangelinos,}

Centre for Environmental Policy and Strategic Environmental Management,

University of the Aegean,

University Hill, Mytilene

Greece

E-mail: kevag@aegean.gr

\section{Antonis Skouloudis}

Henley Business School,

University of Reading,

Greenlands, Henley-on-Thames,

United Kingdom

E-mail: skouloudis@env.aegean.gr

\section{Nikoleta Jones}

Global Sustainability Institute,

Anglia Ruskin University,

East Road, Cambridge

United Kingdom

E-mail: nikoleta.jones@anglia.ac.uk

\section{David Isaac}

Department of Built Environment,

University of Greenwich,

Avery Hill Campus, London

United Kingdom

E-mail: d.isaac@gre.ac.uk

\section{Eleni Sfakianaki}

Hellenic Open University,

Parodos Aristotelous 18, Patra

Greece

E-mail: esfakianaki@eap.gr 


\begin{abstract}
The concept of corporate social responsibility (CSR) and the provision of environmental and social performance information have gained momentum over the past decade. In this respect, the practice of organizational accountability has expanded to include aspects of non-financial nature and issues that can enhance the transparency of business activities and empower stakeholders' decision-making. In this paper we attempt to shed light on the status of CSR reporting of the building and construction industry. Focusing on the UK, we benchmark the CSR reports of building and construction firms against the de facto standard for non-financial reports; the Global Reporting Initiative (GRI) guidelines. Findings indicate that the CSR reporting practices of assessed UK building and construction firms are lacking in key respects, leave much to be desired and have plenty of room for improvement.
\end{abstract}

Keywords: Corporate social responsibility, building and construction firms, sustainability, organizational reporting, organizational stakeholders, United Kingdom.

\title{
Introduction
}

Over the years a paradigm shift over the 'business and society' interplay is being taking place with the aim of delivering positive modifications in organizational performance (Levy, 1997; Starik and Kanashiro, 2013). It is a shift where nonfinancial issues are posed as company-wide responsibilities and not as mere externalities, under the scope of an organizational behavior that seeks confidentiality to accountability, transparency and proactive engagement with stakeholders (Hörisch et al. 2014). In this context, the body of knowledge on organizational responses relating to social responsibility is increasing (De Bakker et al., 2005; Kallio and Nordberg, 2006; Montiel and Delgado-Ceballos, 2014). 
Corporate social responsibility (CSR) poses a wider perspective to organizational performance and accountability, based on all those business actions which affect people, their communities, and their biophysical environment (Lawrence et al., 2005). An array of national as well as international policy-makers, industry associations and advocacy organizations is working towards the consolidation of a meaningful CSR agenda and the incorporation of such practices to existing management techniques and business processes. In this regard, in October 2011, the European Commission ${ }^{1}$ (re-)established its CSR manifestation along with an all-embracing definition: (CSR reflects) "the responsibility of enterprises for their impacts on society" which, in order to be met, an integration process of social, environmental, ethical, human rights and consumer concerns into core business operations and strategy should be in place, in close collaboration with organizational stakeholders.

CSR enables for social and environmental aspects of performance to be more closely examined whilst the incorporation of all three dimensions of the triple-bottom-line (i.e. economic-social-environmental) is imperative for any development of a market response to sustainability. It has been proposed as a 'vehicle' towards sustainable development (Moon, 2007; van Marrewijk and Werre, 2003) and a vital feature of the new global governance regime (Dingwerth and Pattberg, 2009).

The construction industry is a major contributor to the economy and provides most of a country's fixed capital assets which stimulate further growth via its linkages with other industrial sectors and create new employment opportunities (Field and Ofori, 1988). Nevertheless, it represents a highly complex sector with innumerous and multidimensional impacts. Martinuzzi et al (2011) neatly outlines the intrinsic characteristics of the construction business: "the construction sector is characterized 
by the temporal character of a construction site (and the high number and diversity of companies involved), by fierce price competition, by high labour intensity (with short-term labour contracts, seasonal work and wage dumping), by the outstanding role of public procurement, and by the long lifetime of the end product (with the respective effects on energy consumption, health of residents, etc.)" (Martinuzzi et al, 2011, p.1). In this respect, it comprises of various 'new project' or 'repair or maintenance' activities such as public and private housing; infrastructure; public nonhousing; private industrial and commercial non-housing. Each of these sub-sectors does maintain different intrinsic characteristics. Still, they all share a number of interconnected CSR-related issues pertaining to diversity and equality among the workforce, occupational health and safety procedures, training and skills management, benign environmental management, supply chain management, building quality and customer satisfaction, community relations, etc.

Ho (2010) stresses that, despite the lack of published estimates on the cost of business misconduct, the construction sector encompasses an array of challenges related to socially responsible behavior: substandard construction quality, claims games (such as inflated and/or false claims), fraud, conflict of interest, illegal price agreements, unreliable contractors and professional negligence (Ray et al., 1999; May et al., 2001; Vee and Skitmore, 2003; Fan et al., 2001; Glass and Simmonds, 2007; Bowen et al., 2007; Graafland, 2004; Mark-Herbert and von Schantz, 2007). In this context, the construction industry is facing increased scrutiny from the civil society (NGOs, advocacy and pressure groups), the media and potential investors or clients. Such intense scrutiny comes as no surprise since construction business traditionally lagged behind other high-impact sectors in terms of responsiveness to non-financial aspects of performance (Myers, 2005) and in the past has been accused as 'dirty, dangerous and old fashioned' (Fairclough, 2002: 30). Ultimately, it poses a challenge to the 
sector to retain its integrity and, thus, its legitimacy (Chartered Institute of Building, 2003). With this in mind, and drawing on the seminal work of Pearce (2006) along with the recent contributions of du Plessis and Cole (2011), Aho (2013), Hill et al. (2013) and Twinn (2013), this study aims to shed light on the content and quality of CSR reports issued by UK companies of the construction and building sector. Research motivations stem from the limited empirical evidence on CSR in the building and construction sector which suggest that further analysis would add to the identification of intrinsic sectoral trends and characteristics pertaining to socially responsible conduct.

The rest of the paper is structured as follows. In the next section the concept of CSRrelated information to the various social constituents. Next, the methodological approach is described and the sample is identified. The subsequent section presents the assessment's findings succeeded by concluding remarks and future research perspectives in the last section of the paper.

\section{Background}

\section{Conceptual underpinnings}

Conceptual underpinnings of CSR reporting primarily refer to the legitimacy, stakeholder and accountability theories. An outline of these three approaches is provided as follows:

Legitimacy theory posits that the organization is developing its activities within a broader social construct and must meet societal norms, demands and expectations in order to retain its 'right to exist', minimize sanctions imposed by wider constituencies and uphold a socially legitimate organizational behavior. Suchman (1995) defines legitimacy as 'a generalized perception or assumption that the actions of an entity are 
desirable, proper, or appropriate within some socially constructed system of norms, values, beliefs, and definitions' (p. 574). This theoretical lens offers a systemsoriented perspective to the business-and-society relationship, where the firms are defined by the social context within it operates. It sets forth a form of a 'social contract' where society provides the company with a range of resources to conduct its activities along with an overarching 'licence to operate', in return for the provision of socially acceptable (i.e. legitimate) business conduct (Mathews, 1993; Deegan, 2002). In cases where the legitimacy of the organization is at stake, various courses of action can be followed. Lindblom (1994) identifies an array of strategic options a firm can adopt in maintaining its legitimacy: i) educate and inform social constituents on organizational performance, ii) change or manipulate public perceptions of its activities or iii) divert external expectations of its performance management. In this context, CSR disclosure has been identified as a valuable legitimation tool employed to convince societal members that the organization is making necessary efforts to achieve (socially) benign performance and fulfill societal expectations.

Closely intertwined with organizational legitimacy, the stakeholder theory of the firm (Freeman, 1984) emphasizes on the effective management of relationship between the business organization and the various social groups that influences and is influenced by (i.e. the stakeholders). This theory challenges the mere maximization of benefits for the shareholders and embodies the necessity of a balancing act among the array of all stakeholder claims. When utilized as a managerial tool the stakeholder approach aims to identify which social constituents are most important and as a result should receive a greater proportion of management attention (Goodpaster, 1991; Frooman, 1999). From the stakeholder viewpoint CSR reporting is identified as an instrument of fruitful engagement and ongoing dialogue between the firm and its stakeholders and potentially successful medium for negotiating such relationships (Roberts, 1992). 
Finally, accountability theory is concerned with the rights to information that relationships between individuals or groups and organizations entail. The concept of accountability refers to the duty to provide an account of the actions for which an entity is held responsible (Gray et al. 1987, Williams 1987, Roberts and Scapens 1985) and has been identified as an "adhesive that binds social systems" (Frink \& Klimonski, 1998). The nature of accountability relationship and the related rights to information are contextually determined by society, most obviously expressed in terms of legal statutes and statutory body regulations and standards (Parker, 2005). In the context of CSR reporting, organizational accountability theory sets forth normative arguments of transparent, material and comprehensive information provision on the social and environmental impacts and potential failure to attain CSR best practices and/or meet legal compliance.

\section{Socially responsible construction}

Socially responsible construction encapsulates a holistic approach (contrary to fragmented responses) where social norms and concerns, ethical standards and sustainability-oriented practices are embraced and integrated to the various steps of the construction cycle. Already in 1992, Toshihiko Ota, drawing on the case of Japan, raised the need for social responsibility and industrial change of construction processes and output in the $21^{\text {st }}$ century (Ota, 1992). A recent wave of studies has explored aspects of socially responsible construction within an array of diverse institutional environments (Kolk and Pinske, 2006; Mark-Herbert and von Schantz, 2007; Othman, 2009; Petrovic-Lazarevic, 2008; Rameezdeen, 2007; Glass and Simmonds, 2007; Ho, 2010; Shen et al., 2010) and suggests that there is plenty of room for CSR to embed in the industry. This strand of contributions to the building and construction literature attempts to highlight governance mechanisms, impact 
management techniques and proactive engagement approaches for the industry to retain its competitiveness along with the social 'license to operate'. In this respect, Myers (2005) and Jones et al. (2006) have investigated CSR disclosure efforts of construction firms and pointed out that such practices are far from common and various CSR topics receive selective and/or limited treatment.

Stakeholders in the building and construction industry are becoming increasingly aware of the sustainability challenges that such activities need to meet something that is evidenced by the rapid establishment of Green Building Councils across the world (World Green Building Council, 2010). Martinuzzi et al, (2011) identify the property developer, the general contractor, the investor, and the future user and owner as the key constituents in the shaping the social and environmental performance of construction. Kaatz et al. (2006, p. 317) suggest that future evolution of building assessment will most likely be supported by stakeholders' empowerment and more active participation in triple-bottom-line decision-making. Additionally, Newcombe (2003) denotes that stakeholders can exert pressures on construction activities through their cumulative power, while Jergeas et al. (2000) reports that concerns raised by such social groups are addressed only reactively and in cases where the efficient implementation of construction projects is undermined. Winch (2003) indicates the risk of contractors to misidentify their client(s) as their individual stakeholder which can affect (and/or is affected) by the construction project's objectives. Likewise, almost a decade ago, Hadi (2001) reported weak communication efforts on behalf of the construction industry with respect to the local communities. With this in mind, a key issue for construction activity is to meet the increased interest for CSR performance information that will empower and optimize stakeholders' decisionmaking and contribute to organizational legitimacy. 
CSR reporting and the provision of environmental and social performance information has gained momentum over the past few decades, stimulated by the growth of socially responsible investments and high-profile failures of the business world to respond to social expectations and norms that created legitimacy deficits and accountability gaps (Livesey and Kearins, 2002; Lützkendorf and Lorenz, 2006; Eurosif, 2012). Guideline frameworks and sets of principles have been devised in order to convey the notion of social responsibility to for-profit entities while stock indices have incorporated such inclusion criteria. For instance, in the FTSE4Good Index, construction is considered one of the high impact sectors and the inclusion criteria are more stringent compared to other business activities (of low-medium impact weighting). Companies that pursue their enlistment in the index need to satisfy certain environmental and social requirements pertaining to corporate policy, management and reporting (Lützkendorf and Lorenz, 2006). Likewise, the Global Reporting Initiative, a primary mover in the establishment of (voluntary) CSR reporting, has issued sector-specific disclosure requirements for the construction and real estate industry in order to promote meaningful performance appraisal (GRI, 2011).

\section{Method and sample identification}

The building and construction industry is one of the major sectors of the UK economy. It employs 2.93 million workers (approximately $10 \%$ of UK's employment) and contributes almost $£ 90$ billion (or $6.7 \%$ of the total value added) to the national economy on an annual basis. Even though the post-2008 economic downturn which hit most developed countries has severely affected the industry, it 
still remains one of the largest in the European region but with a comparatively higher level of sub-contracting and fragmentation (BIS,2013).

A web-based search was conducted between June and September 2012 in order to gather the available CSR reports published by UK building and construction firms for the previous year/reporting period. We relied on the globalreporting.com and corporateregister.com databases where organizations voluntarily submit their CSR reports and thereinafter we focused on corporate websites of large firms that pertain to the building-construction and supporting services sectors. In total 23 CSR reports were gathered (Appendix A) and comprised the material for analysis. The assessment focused only on CSR reports and did not include cross-references to other corporate publications and information available on the internet. Only in the case where links to specific webpages or other publicly-available information about the organization assessed were available, these were then included in the evaluation.

The paper's analysis relies on a scoring system approach. Such methods have been widely employed in document engineering and offer "a technique for gathering data that consists of codifying qualitative information in anecdotal and literary form into categories in order to derive quantitative scales of varying levels of complexity" (Abbot and Monsen, 1979: p.504). We opted for GRI's G3 framework as the benchmark for assessing the disclosed information. The GRI represents an international multistakeholder organization whose primary mission is to elevate the status of CSR reporting and ultimately shape it to a routine and comparable task such as financial reporting is. GRI pursues this vision by disseminating sets of guidelines for effective CSR performance disclosure and capacity building. 
The G3 guidelines refer to 119 topics and performance indicators pertaining to five major sections: i) strategic posture towards sustainability; ii) information outlining the organizational profile and iii) the report's scope and other related parameters; iv) governance mechanisms, commitments to external initiatives and stakeholder engagement processes; v) quantitative and qualitative indicators of economic, environmental and social performance. In this regard, a 5-level scale between 0 and $100 \%$ for each of the GRI-suggested disclosure items-performance indicators was devised. Non-disclosure equaled to zero points, fuzzy statements received 25\%, brief and adequate coverage of the GRI topic were assigned 50\% and $75 \%$ respectively, while the maximum score (100\%) was assigned in cases where disclosure covered the GRI topic in a consistent and concise manner.

(Insert Table 1 here)

Additionally, a moderating factor was introduced to the analysis in order to examine whether fundamental reporting principles are incorporated in the reporting practices of building and construction firms. These principles, pertaining to materiality (M), reliability (R) and stakeholder inclusiveness (S), are also evaluated on a 5-level scale (0-100\%), and their average score formulates the 'MRS' factor. Reports' score on each of the performance indicators is normalized by the maximum possible score (in order to achieve a 0-1 scale) and then multiplied by the MRS factor. The revised total for performance indicators disclosure is summed and then added to the standard disclosures' results (i.e. strategy, organizational profile, report parameters and governance). The revised total score for each report is divided by the maximum score a report can receive on the assessment to give us the final score in percentage. Applying the MRS factor modified all reports' evaluations downwards but it did 
allow us to shed light on whether the critical performance issues (i.e. the 'hard facts') are properly identified, assessed and presented to the reader, i.e. to any potential stakeholder of the company.

Finally, a selection of quotations are included in an attempt to illustrate aspects where consensus or representative disclosures in terms of CSR articulation is identified. While generalizations with respect to reported information are made, impressions such as "reporting entities tend to", "few of the sample firms" or "the majority of CSR reports" are used when more/less than half of the assessed firms reported in a similar perspective.

(Insert Table 2 here)

\section{Findings}

Overall findings reveal that disclosure of CSR information by the sample firms suffers from very heterogeneous patterns and bears considerable variations in comprehensiveness and information quality. None of the building and construction companies of our sample managed to obtain at least half of the maximum points and total scores - without the application of the MRS coefficient range from $7 \%$ to $38 \%$ (average score is 22\%). Incorporating the MRS factor in the analysis brings the overall scores of the reports even lower between $8 \%-28 \%$ and an average score of 14\% (Table 3).

(Insert Table 3 here)

All assessed organizations offered an articulation of their CSR strategy denoting key events and achievements during the reporting period and, to a lesser degree, strategic priorities and key topics of CSR long-range planning as well as broader trends (i.e. macroeconomic) which affect the organization and influence its CSR priorities. Still, 
presentation and analysis of CSR-related risks and opportunities was mostly absent or lacking clarity and inclusivity while an overall emphasis on pragmatic and instrumental approaches to CSR implementation was evident among reporters.

"In 2010 Berkeley developed and launched Vision2020, a ten-year sustainability strategy that defines how we want the business to perform by 2020 and how we are going to get there. Over the past year we have successfully implemented the strategy whilst also further developing our thinking behind it.

We realise that sustainability and financial performance do not exist in isolation from one another and that in fact delivering value to shareholders is integral to running a sustainable business. We have therefore now woven this into Vision2020 strategy and as a result we consider no longer Vision2020 to simply be our sustainability strategy but instead a strategy for the whole business".

(Berkeley Group, Sustainability Report 2011: p.10)

"For us, sustainability means making tomorrow a better place for our people, customers, suppliers, local communities, and investors. We will do this by delivering our 2020 strategy.

We launched this new strategy in 2011, after reviewing our business and engaging with our stakeholders. It has six positive outcomes that encompass Carillion's economic, environmental, and social contributions and impacts. They build on our sustainability achievements to date and provide direction for the next decade".

(Carillion, Sustainability Report 2011: p.21)

"Corporate Responsibility remains at the heart of everything we do. For us, CR does not mean 'doing something nice on the side' - the principles of CR are embedded in all our business practices. Our policy is to be open and transparent in our reporting and maintain a constructive dialogue with stakeholders".

(Places for People, Corporate Responsibility Report 2011: p.10)

"Our main market - the habitat and construction industry - is an area with critical sustainable development challenges. To meet demand, we need to build more, build better and, most importantly, renovate the buildings we live in today. Yet the regulations for building performance and environmental protection are becoming increasingly stringent, and require new building materials and technologies. We will meet this challenge by developing 
innovative products and solutions, engaging with our key stakeholders to progress sustainable construction and demonstrating leadership in the way we manage our supply chain".

(Saint-Gobain UK \& Ireland, Sustainable Development Review 2011: p.10)

"We believe that addressing corporate responsibility $(C R)$ makes sound business sense for our Company as well as being crucial for risk and opportunity management, and is an essential part of good governance".

(Taylor Wimpey, Corporate Responsibility Report 2011: p.4)

In addition, most firms provided adequate information outlining their organizational profile while basic reporting parameters (e.g. reporting cycle, contact point for the report, scope and boundary of disclosed information) were less comprehensive. Reporting entities tended to emphasize on the primary services/products they offer, on information regarding the scale of their activities (e.g. annual turnover, number of employees, total assets) and on awards/distinctions they received during the reporting period. In contrast, information on organizational governance structures and mechanisms were insufficient and fragmentary. While the majority of reports included a breakdown of governance structure of the organizations, including committees under the highest governance body responsible for organizational activities implementation and oversight, only six firms attempted to describe procedures of the highest governance body for overseeing the organization's identification and management of economic, environmental, and social performance. Similarly, processes in place in order to minimize internal conflicts of interest and for the evaluation of the highest governance body's own performance (with respect to economic, environmental, and social performance) are completely omitted and overlooked.

(Insert Table 4 here) 
In terms of reporting principles integration in data collection and disclosure mechanisms, building and construction firms demonstrate weak efforts to robustly incorporate the aspects of materiality, reliability and stakeholdership. It is only half of the assessed firms that describe a process for defining report content, including how CSR topics are prioritized and which are regarded as essential to be managed. Firms tend to misidentify the material CSR topics stemming from their operation, omit to explain their approach in defining the relative importance of CSR issues included in the report or which of those are considered highly important and, thus, should be thoroughly discussed. In this respect, the lack of materiality implies that companies fail to meaningfully reflect the organization's significant economic, environmental, and social impacts, address stakeholders' concerns and facilitate their decisionmaking.

"In 2008, horizon-scanning techniques were used to help identify the issues to address in our 2020 vision and roadmap. In early 2010 we held a series of in-depth workshops to consider what additional issues should be included for our sustainability reporting. Members of the executive team and other senior managers took part in these workshops to help prioritise the issues we should give most weight to our sustainability reports.

(...) During the refresh of our roadmap in 2012, we will undertake a comprehensive materiality review to check that the issues we have identified as material remain valid and what changes (if any) are required to focus on what matters in our future reporting".

(Balfour Beatty, Sustainability Report 2011: p.14)

"Through the course of our business, which includes dialogue with our stakeholders, benchmarking our performance and working with others, we define our sustainability priorities ('material topics') on an ongoing basis'.

(Crest Nicholson, Sustainability Report 2010/11: p.33)

"We recently updated our materiality review to help us understand our key risks and opportunities both now and looking ahead. This process played an instrumental role in 
determining the content of this report. The update included a review of our key stakeholders and their perspectives on our Vision2020 strategy, our sustainability policies, leading benchmark criteria and all the key policy updates that occurred during 2010/11".

(Berkeley Group, Sustainability Report 2011: p.66)

"Our sustainability policy sets out the principles underpinning our approach through our key philosophies: People; Customers; Partners; and Planet; together with our Health and Safety performance, and replaces our previously reported Charters.(...) The philosophies were developed and are owned by a team of senior managers and encapsulate our approach to mitigating the key social, environmental and economic risks at every stage of the business cycle from the acquisition of land, through planning, design and construction to sales and after-sales customer service”.

(Barratt Developments, Sustainability Report 2011: p.3)

In the same vein, the vast majority of sample companies denote stakeholder groups engaged by the organization but only a few of them clarifies the process(es) for determining the organizational stakeholders groups. In addition, neither approaches to stakeholder engagement (e.g. frequency of engagement by type and by stakeholder group), nor key topics-concerns raised through stakeholder engagement (or how the company has responded to such key issues, including through its report) are adequately presented.

"In considering stakeholder views, we discussed what we believed were the views of stakeholders from existing knowledge within the business. We did not consult stakeholders directly in this assessment".

(Balfour Beatty, Sustainability Report 2011: p.16)

"A sustainability workshop was held where we drew up a list of all the stakeholders that we engage with. We then grouped similar stakeholders together and developed 9 key stakeholder groups that are important to our business. We decided to engage with all these stakeholder groups on the basis of their importance to the success of our business".

(Kingspan Group, Sustainability Report 2010/11: p.44) 
"Stakeholder engagement is guided by a clear process set out in our stakeholder framework, involving:

- recognising the need for engagement

- identifying relevant stakeholders and impacts

- deciding on forms of engagement and recording the outcomes".

(Carillion, Sustainability Report 2010/11: p.29)

"We want to learn from others, consult on our approach, share ideas and ensure the Group plays its part in delivering a sustainable economy. We strive to demonstrate to all of the stakeholders in our business that we provide sustainable solutions and services.

We seek to influence them to address the sustainable development agenda in their dealings with us.

(...) This year we launched a set of best practice planning guidelines to ensure each community and stakeholder interaction is of the high standards we aspire to".

(Galliford Try, Corporate Responsibility Report 2011: p.10,14)

"Costain Cares is not a slogan. It is an attitude of mind. It is a commitment to exemplary behaviour and a touchstone against which we can all evaluate and measure our performance.

We have listened to the views of customers, communities, colleagues, supply chain partners and shareholders. This process has highlighted the issues that matter. It has allowed us to assess what we are doing well and identify where we need to focus for the future. We have used this feedback to set ambitious goals against which we can be held to account. Costain Cares is based on relationships, our environment and the future".

(Costain Group, Annual Report 2011: p.18)

Nevertheless, the most significant shortcoming in terms of reporting principles integration is the lack of credibility of the disclosed information: it is only four firms that sought for (partial) assurance of their report's content and included the assurance provider's statement. The rest of the sample companies either included fuzzy information or overlooked the task of external verification for the reported information. 
"Our approach to report assurance follows the AA1000 Assurance Standard (inclusive, reflects material issues and is responsive to stakeholder concerns)".

(Balfour Beatty, Sustainability Report 2010/11: p.85)

"The AA1000 Assurance Standard (2008) principles have been used as a basis for this verification activity. A Type 2 Assurance has been agreed with the client to evaluate the reliability of the specified sustainability performance information. This engagement has been conducted to provide a moderate level of assurance as defined by the standard".

(Barratt Developments, Sustainability Report 2010/11: p.25)

"Carillion selected a range of targets for external assessment. (...) Bureau Veritas has been commissioned by Carillion plc to review progress against a selection of its 2011 sustainability targets and to provide independent verification of the stated level of achievement of the identified targets. The objective of this process is to provide assurance to Carillion's stakeholders over the achievement of the selected targets and the reliability of associated information and data within Carillion plc's 2011 Sustainability Report (...)”.

(Carillion, Sustainability Report 2010/11: p.14)

"Where available we use recognised methodologies for measuring and presenting our performance data, and have stated where this is not the case. This includes adhering to the Global Reporting Initiative's guidelines where appropriate. Our carbon data is verified against international guidelines by Verco Advisory Services Ltd, formerly Camco UK. The sustainability report content in the 2011Annual Report and Accounts has been externally audited by KPMG. While we have not had our sustainability report independently verified this year and our approach to assurance is reviewed annually".

(Crest Nicholson, Sustainability Report 2010/11: p.33)

"We use the Index to benchmark our performance with other companies, but more importantly, it helps us to understand exactly where we can do better and how we can improve. Our submission into the Index is audited internally by our Business Assurance team every year and we have now obtained the ISO14001 certification through which we can independently verify our environmental performance".

(Places for People, Corporate Responsibility Report 2011: p.10) 
All companies explicitly provided information of social, environmental, and economic performance in their sustainability reports through quantitative as well as qualitative indicators.

Economic performance is mostly articulated through an analysis of the direct economic value that is generated and distributed, including revenues, operating costs, retained earnings, and payments to capital providers and governments. Moreover, assessed firms tend to emphasize on donations and community investments, i.e. the development of infrastructure investments and services provided primarily for public benefit through commercial, in-kind, and/or pro bono engagement. In contrast, it is only three construction firms that disclose their approach to spending on locallybased suppliers and towards local hiring of employees.

Aspects of environmental performance are presented in a piecemeal manner mainly through: i) total water consumption during the reporting period, ii) aggregated greenhouse gas emissions generated by organizational activities, iii) a breakdown of waste volume by type and/or disposal methods along with iv) various internal initiatives for the mitigation of environmental impacts, primarily by endorsing energy-efficient or renewable energy-based buildings/constructions and actively planning for reduced greenhouse gas emissions. Only few of the sample firms provided comprehensive performance information with respect to energy consumption, the volume or weight of materials used in their construction/building projects or their approach for managing their impacts on biodiversity. Likewise, even less companies clarified their total environmental protection expenditures and investments as well as whether fines or non-monetary sanctions for non-compliance with environmental regulation have been imposed to them. Finally, the identification 
of significant environmental impacts of the transportation of building materials and other goods for the organization's operations (including transporting members of the workforce) is an aspect of performance that is missing from the majority of CSR reports.

Social performance indicators are mostly limited to labor practices with companies to indicate rates of injury, occupational accidents or work-related lost days and describe internally developed programs for skills management and life-long learning of the workforce. Issues referring to human rights protection are not covered in reports; only one company discloses information on investment agreements that include human rights clauses or that have undergone human rights screening and two include information on suppliers and contractors which undergo screening on human rights. Still, while it is only two that discuss their approach to contributing to the elimination of child labor, none is attempting to explain how the issue of forced/compulsory labor is managed or how collective bargaining and freedom of association on behalf of their employees is facilitated. Disclosure of performance information on broader societal perspectives of organizational performance is relatively uncommon with only one firm to adequately disclose its approach against corruption. In this respect, all reports provided mostly fuzzy statements on actions taken against anti-competitive behavior, anti-trust or monopoly practices and, most importantly, on programs and practices in place which assess and manage the impacts of construction operations on local communities (during the whole period of the building/construction cycle). Finally, product responsibility is articulated through surveys measuring end users' (clients') satisfaction while less than half of the assessed reports offer information on life-cycle stages in which health and safety impacts of buildings/constructions on end users are assessed for improvement. 
(Insert Table 5 here)

\section{Discussion}

The delivery and operation of a socially responsible built environment requires more than sophisticated design and technological innovations. It postulates a holistic approach in embedding CSR considerations throughout the construction cycle, identifying and effectively managing risks and opportunities that emerge from the CSR agenda and exhibit an explicit and sustained focus to socially responsible performance. Aspects of environmental management, human resources management, health and safety, corporate governance, supply chain management, human rights protection, customer satisfaction and community engagement should receive increased attention. Moreover, organizational efforts to respond to such CSR challenges and should be comprehensively communicated to all affected social constituents that maintain the 'right to know' on the all-encompassing impacts of construction activities.

Our paper suggests that the CSR reporting practices of assessed UK building and construction firms leave much to be desired, as the work of Lamprinidi and Ringland (2008) and Glass (2012) had previously indicated for the sector on a global scale. Our findings also confirm the preliminary evidence of Myers (2005) and Jones et al. (2006) while underline the need for a more in-depth examination of the impacts of construction on society which the seminal work of Professor David Pearce had set forth. Likewise, the study's results are in line with KPMG's (2011) plot of CSR reporting quality/maturity level for the various business sectors, where the construction industry is identified as gaining limited traction so far for either implementing or communicating about its CSR efforts and/or achievements. As 
KPMG denotes the construction companies are not demonstrating significant results regarding the growing maturity of their information systems and processes and they have not implemented information systems and processes to a level akin to leading CSR reporting entities (KPMG, 2011, p.5). In addition, the studies of Skouloudis et al. $(2010 ; 2012)$ where the GRI guidelines have been applied as benchmark to diverse samples also highlight (from a comparative standpoint and perspective) that the practice of CSR reporting is currently not well-established in UK's construction firms.

(Insert Table 6 here)

Most firms have a long way to go before they shape an effective channel of information flows that will potentially empower the stakeholders' decision-making processes and facilitate the transparency of organizational performance. While the commitment to integrate CSR in core business strategy and operations is sufficiently expressed by construction companies, most of them fall short in adequately disclosing key performance aspects and in seeking third-party assurance for the disclosed performance data. Therefore, as Twinn (2003) points out, if building professionals are to make a meaningful contribution in society, they need "to fill the large communications gap in society's appreciation of sustainability" as well as to "to be concise, quick, relevant and balanced in response to topical issues; and to present information in ways that speak directly to different and wider audiences with economic, political, social or environmental standpoints" (p.128).

\section{Conclusions}

The disclosure of CSR information should serve as a catalyst to the discharge of social (i.e. non-financial) accountability and fruitful stakeholder communication and 
engagement. However, the majority of sample firms do not avoid the pitfalls of 'window-dressing' and superficial information provision. They tend to emphasize on taken-for-granted aspirations such as those identified in Tregida et al. (2013). They avert from aspects of negative CSR performance, such as the clarification whether fines and sanctions have been imposed due to improper conduct during the reporting period, and also seem to pass by the 'hard facts' which would offer the reader (and potential stakeholder of the company) a comprehensive depiction of the CSR efforts of the organization. The assessed reports lack balance, completeness and comparability but the most important shortcoming is the absence of reliability of the available disclosed (performance) information achieved through assurance processes. In this context, the GRI reporting guidelines along with the sector-specific supplement (Construction and Real Estate Sector Supplement - CRESS) that the organization has issued, offer a meaningful approach to CSR reporting which would enable the management of building and construction firms to develop effective data collection mechanisms and prepare comprehensive (i.e. material and stakeholderspecific) CSR information flows.

With this in mind, future research should examine the CSR embeddedness and the related reporting practices of building and construction companies in different national (and consequently institutional) environments. Additionally, by employing an action research approach, researchers could shed light on the procedures and processes within a construction firm that pertain to the preparation of the CSR report and the issues that need to be resolved for effective accountability practices, beyond the scope of public relations and the pursue of reputational gains. 


\section{Endnotes}

[1] Since the publication of the Green Book (2001) the European Commission has been a trend-setter and influential actor in promoting CSR in the business community.

\section{References}

Aho, I. (2013) Value-added business models: linking professionalism and delivery of sustainability. Building Research \& Information, 41(1), 110-114.

Bowen, P., Akintoye, A., Pearl, R. and Edwards, P.J. (2007) Ethical behaviour in the South African construction industry. Construction Management and Economic, 6, 631-648.

Chartered Institute of Building (2003) Corporate social responsibility and construction, available at: http://support.freecpd.net/support_data/1/Reports/csr.pdf

de Bakker, F.G.A., Groenewegen, P. and den Hond, F. (2005) A bibliometric analysis of 30 years of research and theory on corporate social responsibility and corporate social performance. Business and Society, 44(3), 283-317.

Dingwerth, K. and Pattberg, P. (2009) World politics and organizational fields: The case of transnational sustainability governance. European Journal of International Relations, 15(4), 707-743.

du Plessis, C. and Raymond, J.C. (2011) Motivating change: shifting the paradigm, Building Research \& Information, 39(5), 436-449.

Eurosif (2012) European SRI Study, available at: http://www.eurosif.org/research/eurosif-sri-study.

Fairclough, J. (2002) Rethinking construction innovation and research: A review of government $R \& D$ policies and practices, available at: http://ww.dti.gov.uk/construction/pdf/clough.pdf.

Fan, L., Ho, M.F. and Ng, V. (2001) A study of quantity surveyors' ethical behaviour. Construction Management and Economics, 19(1), 19-36.

Field, B. and Ofori, G. (1988) Construction and economic development - A case study. Third World Planning Review, 10(1), 41-50.

Glass, J. (2012) The state of sustainability reporting in the construction sector. Smart and Sustainable Built Environment, 1(1), 87-104.

Glass, J. and Simmonds, M. (2007) 'Considerate construction': Case studies of current practice. Engineering, Construction and Architectural Management, 14(2), 131-149.

Global Reporting Initiative - GRI (2006) GRI G3 reporting guidelines, Global Reporting Initiative, Amsterdam. 
Global Reporting Initiative - GRI (2011) Construction and Real Estate Sector Supplement, Global Reporting Initiative, Amsterdam.

Graafland, J. (2004) Collusion, reputation damage and interest in code of conduct: The case of a Dutch construction company. Business Ethics: A European Review, 13(2/3), 127-142.

Hadi, M. (2001) Working with the community: Impacts report for general dissemination, available at: http://projects.bre.co.uk/productive_workplace/pdf/ImpactsOfConstruction.pdf.

Hill, S., Lorenz, D., Dent, P. and Lützkendorf, T. (2013) Professionalism and ethics in a changing economy. Building Research \& Information, 41(1), 8-27.

Ho, C.M.F. (2010) A critique of corporate ethics codes in Hong Kong construction. Building Research \& Information, 38(4), 411-427.

Jergeas, G.E., Williamson, E., Skulmoski, G.J. and Thomas, J.L. (2000) Stakeholder management on construction projects. AACE International Transactions, 12, 1-5.

Jones, P., Comfort, D. and Hillier, D. (2006) Corporate social responsibility and the UK construction industry. Journal of Corporate Real Estate, 8(3), 134-150.

Kaatz, E., Root, D.S., Bowen, P.A. and Hill, R.C. (2006) Advancing key outcomes of sustainability building assessment. Building Research \& Information, 34(4), 308320.

Kolk, A. and Pinkse, J. (2006) Stakeholder mismanagement and corporate social responsibility crises. European Management Journal, 24(1), 59-72.

KPMG (2011) International survey of corporate responsibility reporting 2011, KPMG Global Sustainability Services, Amsterdam, the Netherlands.

Krippendorff, K. (2004) Content analysis: An introduction to its methodology, Sage, Thousand Oaks, CA.

Lamprinidi, S. and Ringland, L. (2008) A snapshot of sustainability reporting in the construction and real estate sector, Global Reporting Initiative, Amsterdam.

Lawrence, A.T., Weber, J. and Post, J.E. (2005) Business and society: Stakeholders, ethics, public policy, McGraw-Hill, New York.

Lützkendorf, T. and Lorenz, D.P. (2006) Using an integrated performance approach in building assessment tools. Building Research \& Information, 34(4), 334-356.

Mark-Herbert, C. and Schantz, C. (2007) Communicating corporate social responsibility - Brand management. Electronic Journal of Business Ethics and Organization Studies,12(2), 4-11.

Martinuzzi, A., Kudlak, R., Faber, C. and Wiman, A. (2011) CSR activities and impacts of the construction sector, Research Institute for Managing Sustainability (RIMAS) Working Papers No. 1/2011, Vienna University of Economics and Business. 
May, D., Wilson, O.D. and Skitmore, R.M. (2001) Bid cutting: an empirical study of practice in south-east Queensland. Engineering, Construction and Architectural Management, 8(4), 250-256.

Moon, J. (2007) The contribution of corporate social responsibility to sustainable development. Sustainable Development, 15, 296-306.

Myers, D. (2005) A review of construction companies' attitudes to sustainability. Construction Management and Economics, 23(8), 781-785.

Newcombe, R. (2003) From client to project stakeholders: A stakeholder mapping approach. Construction Management and Economics, 21(8), 841-848.

Ota, T. (1992) Social responsibility and contribution: R\&D for the construction industry in the twenty-first century. Building Research \& Information, 20(5), 273280.

Othman, A.A.E. (2009) Corporate social responsibility of architectural design firms towards a sustainable built environment in South Africa, Architectural Engineering And Design Management, 5(1/2), 36-45.

Pearce, D. (2006) Is the construction sector sustainable?: Definitions and reflections. Building Research \& Information, 34(3), 201-207.

Petrovic-Lazarevic, S. (2008) The development of corporate social responsibility in the Australian construction industry. Construction Management and Economics, 26(2), 93-101.

Rameezdeen, R. (2007) Image of the construction industry, in Sexton, M., Kahkonen, K. and Lu, S. L. (eds), CIB Priority Theme - Revaluing Construction: A W065 'Organisation and Management of Construction' Perspective, CIB Publication 313, 76-87.

Ray, R.S., Hornibrook, J., Skitmore, R.M. and Zarkada, A. (1999) Ethics in tendering: A survey of Australian opinion and practice. Construction Management and Economics, 17(2), 139-153.

Shen, L., Tam, V.W.Y., Tam, L. and Ji, Y. (2010) Project feasibility study: The key to successful implementation of sustainable and socially responsible construction management practice. Journal of Cleaner Production, 18(3), 254-259.

Skouloudis, A., Evangelinos, K. and Kourmousis, F. (2010) Assessing non-financial reports according to the Global Reporting Initiative guidelines: Evidence from Greece. Journal of Cleaner Production,18(5), 426-438.

Skouloudis, A., Konstantinos, E. and Stavros, M. (2012) Accountability and stakeholder engagement in the airport industry: An assessment of airports' CSR reports. Journal of Air Transport Management, 18(1), 16-20.

Twinn, C. (2013) Professionalism, sustainability and the public interest: What next? Building Research \& Information, 41(1), 123-128. 
van Marrewijk, M. and Werre, M. (2003) Multiple levels of corporate sustainability. Journal of Business Ethics, 44(2/3), 107-120.

Vee, C. and Skitmore, M. (2003) Professional ethics in the construction industry. Journal of Engineering, Construction and Architectural Management, 10(2), 117127.

Winch, G.M. (2002) Managing Construction Projects, Blackwell Science, Oxford.

World Green Building Council (2010) World Green Building Council Membership 2010, available at: http://www.worldgbc.org.

\section{Appendix}

Companies whose CSR reports were included in the study:

Balfour Beatty Plc

Barratt Developments Plc

Berkeley Group Holdings Plc

Bovis Homes Group Plc

Carillion Plc

Costain Group Plc

Countryside Properties Plc

Crest Nicholson Plc

Galliford Try Plc

Interserve Plc

ISG InteriorExterior Plc

John Laing Plc

Kier Group Plc

Kingspan Group Plc

Marshalls Plc

NG Bailey Ltd

North Midland Construction Plc

Places for People

Rider Levett Bucknall UK Ltd

Saint-Gobain Building Distr. UK \& Ireland Ltd

Simons Construction Ltd

Sir Robert McAlpine Ltd

Taylor Wimpey Plc

$\begin{array}{cc}\text { Revenue (£m) } & \text { Employees } \\ 9,494 & 50,000 \\ 2,035.4 & 4,400 \\ 742.6 & 935 \\ 364.8 & 560 \\ 4,153.2 & 45,342 \\ 986.3 & 5,000 \\ 222 & 473 \\ 319.1 & 494 \\ 1,284 & 3,665 \\ 2,320 & 20,308 \\ 1,196 & 2,527 \\ 282 & 1,210 \\ 2,179 & 10,700 \\ 1125.5 & 986 \\ 334 & 2,361 \\ 419 & 2,575 \\ 167.2 & 987 \\ 339.6 & 2,430 \\ 61 & 335 \\ 2,400 & 12,561 \\ 99.9 & 340 \\ 743 & 1,331 \\ 1,808 & 3,529\end{array}$




\begin{tabular}{|c|l|}
\hline Points & \multicolumn{1}{c|}{ Rating qualifications/requirements } \\
\hline 0 & $\begin{array}{l}\text { The report does not include any information relevant to the specific GRI } \\
\text { topic/indicator. No coverage. }\end{array}$ \\
\hline 1 & $\begin{array}{l}\text { The report provides generic or brief statements, without specific } \\
\text { information on the organisations approach to the topic/indicator. }\end{array}$ \\
\hline 2 & $\begin{array}{l}\text { The report includes valuable information on the topic/indicator but there are } \\
\text { still major gaps in coverage. The organisation identifies the assessed issue, } \\
\text { but fails to present it sufficiently. }\end{array}$ \\
\hline 3 & $\begin{array}{l}\text { The provided information is adequate and clear. It is evident that the } \\
\text { reporting organisation has developed the necessary systems and processes } \\
\text { for data collection on the assessed topic/indicator and attempts to present it } \\
\text { in a consistent manner. }\end{array}$ \\
\hline 4 & $\begin{array}{l}\text { Coverage of the specific issue can be characterised as "full" in the report. It } \\
\text { provides the organisation's policy, procedures/programs and relevant } \\
\text { monitoring results for addressing the issue. The organisation meets the GRI } \\
\text { requirements, allowing comparison with other organisations. }\end{array}$ \\
\hline
\end{tabular}

Table 1: Basic rating qualification scale

\begin{tabular}{|c|l|}
\hline Reporting principle & \multicolumn{1}{|c|}{ Definition } \\
\hline Materiality & $\begin{array}{l}\text { The information in a report should cover topics and } \\
\text { indicators that reflect the organization's significant economic, } \\
\text { environmental, and social impacts or that would substantively } \\
\text { influence the assessments and decisions of stakeholders. }\end{array}$ \\
\hline Reliability & $\begin{array}{l}\text { Information and processes used in the preparation of a report } \\
\text { should be gathered, recorded, compiled, analyzed, and } \\
\text { disclosed in a way that could be subject to examination and } \\
\text { that establishes the quality and materiality of the information. }\end{array}$ \\
\hline Stakeholder & $\begin{array}{l}\text { The reporting organization should identify its stakeholders } \\
\text { and explain in the report how it has responded to their } \\
\text { reasonable expectations and interests. }\end{array}$ \\
\hline
\end{tabular}

Table 2: The principles comprising the moderating factor of the assessment method.

Source: Global Reporting Initiative - Sustainability Reporting Guidelines G3, 2006. 


$\begin{array}{ccc}\begin{array}{c}\text { Construction } \\ \text { firm }\end{array} & \text { Total score } & \begin{array}{c}\text { Total score w/o the } \\ \text { MRS coefficient }\end{array} \\ \text { C1 } & \mathbf{2 8 \%} & 38 \% \\ \text { C2 } & \mathbf{2 4 \%} & 33 \% \\ \text { C3 } & \mathbf{2 0 \%} & 30 \% \\ \text { C4 } & \mathbf{1 9 \%} & 26 \% \\ \text { C5 } & \mathbf{1 9 \%} & 33 \% \\ \text { C6 } & \mathbf{1 9 \%} & 27 \% \\ \text { C7 } & \mathbf{1 8 \%} & 30 \% \\ \text { C8 } & \mathbf{1 8 \%} & 30 \% \\ \text { C } 9 & \mathbf{1 4 \%} & 27 \% \\ \text { C10 } & \mathbf{1 3 \%} & 24 \% \\ \text { C11 } & \mathbf{1 3 \%} & 21 \% \\ \text { C12 } & \mathbf{1 3 \%} & 18 \% \\ \text { C13 } & \mathbf{1 2 \%} & 24 \% \\ \text { C14 } & \mathbf{1 1 \%} & 20 \% \\ \text { C15 } & \mathbf{1 1 \%} & 19 \% \\ \text { C16 } & \mathbf{1 0 \%} & 18 \% \\ \text { C17 } & \mathbf{1 0 \%} & 16 \% \\ \text { C18 } & \mathbf{9 \%} & 15 \% \\ \text { C19 } & \mathbf{8 \%} & 14 \% \\ \text { C20 } & \mathbf{8 \%} & 13 \% \\ \text { C21 } & \mathbf{8 \%} & 13 \% \\ \text { C22 } & \mathbf{7 \%} & 15 \% \\ \text { C23 } & \mathbf{3 \%} & 7 \% \\ 3: 0 \% & \end{array}$

Table 3: Overall assessment scores of CSR reports.

$\begin{array}{ccccc}\begin{array}{c}\text { Construction } \\ \text { firm }\end{array} & \begin{array}{c}\text { Vision and } \\ \text { strategy }\end{array} & \begin{array}{c}\text { Organizational } \\ \text { profile }\end{array} & \begin{array}{c}\text { Report } \\ \text { parameters }\end{array} & \text { Governance } \\ \text { C1 } & 63 \% & 67 \% & 54 \% & 51 \% \\ \text { C2 } & 25 \% & 92 \% & 77 \% & 26 \% \\ \text { C3 } & 38 \% & 83 \% & 60 \% & 24 \% \\ \text { C4 } & 63 \% & 28 \% & 56 \% & 25 \% \\ \text { C5 } & 75 \% & 42 \% & 48 \% & 24 \% \\ \text { C6 } & 38 \% & 58 \% & 65 \% & 10 \% \\ \text { C7 } & 38 \% & 61 \% & 48 \% & 13 \% \\ \text { C8 } & 38 \% & 47 \% & 63 \% & 29 \% \\ \text { C9 } & 38 \% & 72 \% & 29 \% & 24 \% \\ \text { C10 } & 50 \% & 58 \% & 48 \% & 10 \% \\ \text { C11 } & 38 \% & 69 \% & 52 \% & 10 \% \\ \text { C12 } & 38 \% & 53 \% & 38 \% & 24 \% \\ \text { C13 } & 25 \% & 61 \% & 27 \% & 26 \% \\ \text { C14 } & 38 \% & 53 \% & 27 \% & 25 \% \\ \text { C15 } & 50 \% & 64 \% & 21 \% & 21 \% \\ \text { C16 } & 25 \% & 33 \% & 44 \% & 16 \% \\ \text { C17 } & 38 \% & 36 \% & 31 \% & 24 \% \\ \text { C18 } & 38 \% & 50 \% & 23 \% & 13 \% \\ \text { C19 } & 50 \% & 36 \% & 15 \% & 16 \% \\ \text { C20 } & 38 \% & 28 \% & 31 \% & 15 \% \\ \text { C21 } & 38 \% & 22 \% & 35 \% & 12 \% \\ \text { C22 } & 25 \% & 56 \% & 8 \% & 10 \% \\ \text { C23 } & 25 \% & 17 \% & 4 \% & 7 \%\end{array}$

Table 4: Assessment results on sections containing standard qualitative information. 


\begin{tabular}{|c|c|c|c|c|c|c|c|}
\hline Construction firm & $\begin{array}{c}\text { Economic } \\
\text { performance }\end{array}$ & $\begin{array}{c}\text { Environmental } \\
\text { performance }\end{array}$ & $\begin{array}{c}\text { Social } \\
\text { performance }\end{array}$ & $\begin{array}{c}\text { Labor } \\
\text { Practices }\end{array}$ & $\begin{array}{l}\text { Human } \\
\text { rights }\end{array}$ & $\begin{array}{l}\text { Broader societal } \\
\text { issues }\end{array}$ & $\begin{array}{c}\text { Product/service } \\
\text { responsibility }\end{array}$ \\
\hline C1 & $15 \%(31 \%)$ & $16 \%(34 \%)$ & $12 \%(24 \%)$ & $13 \%(27 \%)$ & $1 \%(3 \%)$ & $27 \%(56 \%)$ & $7 \%(14 \%)$ \\
\hline $\mathrm{C} 2$ & $6 \%(17 \%)$ & $13 \%(36 \%)$ & $5 \%(13 \%)$ & $11 \%(30 \%)$ & $0 \%$ & $0 \%$ & $3 \%(8 \%)$ \\
\hline C3 & $6 \%(19 \%)$ & $11 \%(39 \%)$ & $2 \%(7 \%)$ & $5 \%(16 \%) 0$ & $0 \%$ & $2 \%(6 \%)$ & $0 \%$ \\
\hline $\mathrm{C} 4$ & $6 \%(11 \%)$ & $14 \%(28 \%)$ & $9 \%(18 \%)$ & $15 \%(30 \%)$ & $0 \%$ & $13 \%(25 \%)$ & $6 \%(22 \%)$ \\
\hline C5 & $6 \%(22 \%)$ & $11 \%(38 \%)$ & $8 \%(28 \%)$ & $7 \%(23 \%)$ & $10 \%(33 \%)$ & $12 \%(41 \%)$ & $5 \%(17 \%)$ \\
\hline $\mathrm{C} 6$ & $10 \%(25 \%)$ & $10 \%(25 \%)$ & $7 \%(16 \%)$ & $11 \%(27 \%)$ & $5 \%(11 \%)$ & $1 \%(3 \%)$ & $7 \%(17 \%)$ \\
\hline C7 & $8 \%(22 \%)$ & $13 \%(36 \%)$ & $19 \%(21 \%)$ & $13 \%(38 \%)$ & $0 \%$ & $7 \%(19 \%)$ & $6 \%(17 \%)$ \\
\hline $\mathrm{C} 8$ & $4 \%(17 \%)$ & $8 \%(33 \%)$ & $3 \%(15 \%)$ & $8 \%(36 \%)$ & $0 \%$ & $3 \%(13 \%)$ & $0 \%$ \\
\hline C9 & $1 \%(6 \%)$ & $3 \%(31 \%)$ & $2 \%(20 \%)$ & $4 \%(38 \%)$ & $0 \%$ & $2 \%(16 \%)$ & $2 \%(17 \%)$ \\
\hline C10 & $2 \%(25 \%)$ & $2 \%(23 \%)$ & $1 \%(15 \%)$ & $2 \%(25 \%)$ & $0 \%$ & $1 \%(13 \%)$ & $1 \%(17 \%)$ \\
\hline C11 & $1 \%(11 \%)$ & $2 \%(15 \%)$ & $1 \%(11 \%)$ & $2 \%(20 \%)$ & $1 \%(8 \%)$ & $1 \%(13 \%)$ & $0 \%$ \\
\hline $\mathrm{C} 12$ & $1 \%(8 \%)$ & $1 \%(4 \%)$ & $2 \%(13 \%)$ & $1 \%(9 \%)$ & $4 \%(31 \%)$ & $2 \%(16 \%)$ & $0 \%$ \\
\hline C13 & $0,3 \%(17 \%)$ & $1 \%(33 \%)$ & $0,1 \%(7 \%)$ & $0,3 \%(13 \%)$ & $0 \%$ & $0,2 \%(9 \%)$ & $0,1 \%(3 \%)$ \\
\hline C14 & $1 \%(11 \%)$ & $1 \%(18 \%)$ & $1 \%(10 \%)$ & $1 \%(23 \%)$ & $0 \%$ & $0,2 \%(3 \%)$ & $0,3 \%(6 \%)$ \\
\hline C15 & $1 \%(25 \%)$ & $0,2 \%(10 \%)$ & $0,2 \%(12 \%)$ & $0,3 \%(16 \%)$ & $0 \%$ & $0,4 \%(19 \%)$ & $0,2 \%(11 \%)$ \\
\hline C16 & $0,4 \%(19 \%)$ & $0,3 \%(14 \%)$ & $0,2 \%(9 \%)$ & $0,4 \%(18 \%)$ & $0 \%$ & $0,1 \%(6 \%)$ & $0,1 \%(6 \%)$ \\
\hline C17 & $0 \%(3 \%)$ & $0 \%(13 \%)$ & $0 \%(8 \%)$ & $0 \%(14 \%)$ & $0 \%$ & $0 \%(6 \%)$ & $0 \%(6 \%)$ \\
\hline C18 & $2 \%(25 \%)$ & $1 \%(10 \%)$ & $0,4 \%(6 \%)$ & $1 \%(9 \%)$ & $0 \%$ & $1 \%(9 \%)$ & $0,3 \%(6 \%)$ \\
\hline C19 & $1 \%(8 \%)$ & $2 \%(14 \%)$ & $1 \%(8 \%)$ & $2 \%(13 \%)$ & $0 \%$ & $1 \%(9 \%)$ & $1 \%(6 \%)$ \\
\hline C20 & $1 \%(11 \%)$ & $1 \%(8 \%)$ & $1 \%(7 \%)$ & $1 \%(13 \%)$ & $0 \%$ & $0,3 \%(3 \%)$ & $1 \%(8 \%)$ \\
\hline $\mathrm{C} 21$ & $0,2 \%(3 \%)$ & $1 \%(14 \%)$ & $0,3 \%(5 \%)$ & $1 \%(11 \%)$ & $0 \%$ & $0,2 \%(3 \%)$ & $0,2 \%(3 \%)$ \\
\hline $\mathrm{C} 22$ & $0,1 \%(3 \%)$ & $1 \%(15 \%)$ & $0,5 \%(21 \%)$ & $1 \%(21 \%)$ & $0 \%$ & $0,4 \%(9 \%)$ & $0,5 \%(11 \%)$ \\
\hline C23 & $0,3 \%(8 \%)$ & $0,2 \%(6 \%)$ & $0,3 \%(2 \%)$ & $0,4 \%(9 \%)$ & $0,1 \%(3 \%)$ & $0,1 \%(3 \%)$ & $0,3 \%(3 \%)$ \\
\hline
\end{tabular}

Table 5: Assessment results on CSR performance information

(Figures in brackets denote the results without the application of the MRS coefficient). 
Table 6: Summary of findings

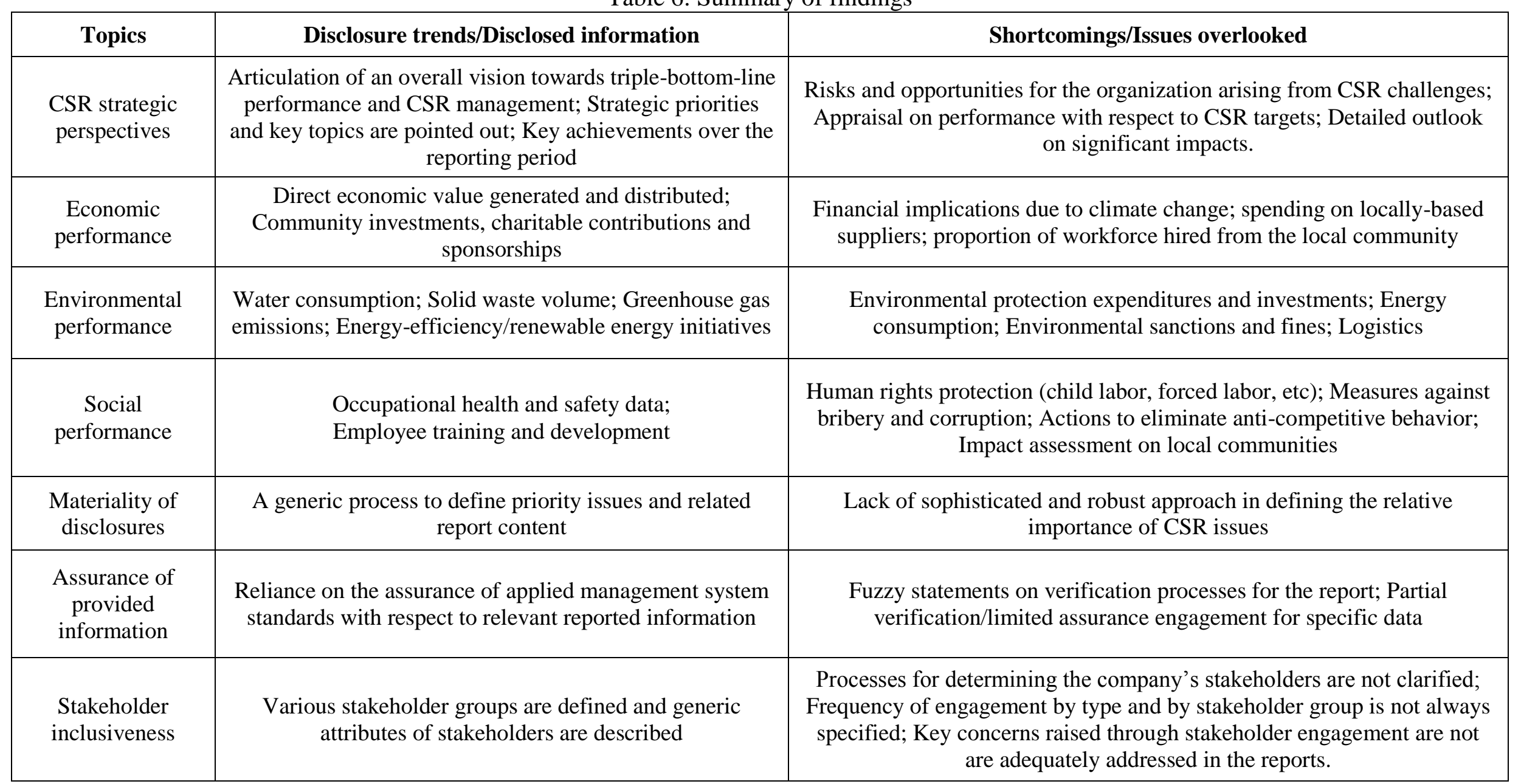

